\title{
Relationships among body mass, brain size, gut length, and blood tryptophan and serotonin in young wild-type mice Ricardo Albay III ${ }^{1}$, Angela Chen ${ }^{1}$, George M Anderson ${ }^{2}$, Maggie Tatevosyan ${ }^{1}$ and Skirmantas Janušonis*1
}

\author{
Address: ${ }^{1}$ Department of Psychology, University of California, Santa Barbara, California, USA and ${ }^{2}$ Yale University Child Study Center, New \\ Haven, Connecticut, USA \\ Email: Ricardo Albay - albay3@umail.ucsb.edu; Angela Chen - angc_84@hotmail.com; George M Anderson - george.anderson@yale.edu; \\ Maggie Tatevosyan - mtatevosyan@umail.ucsb.edu; Skirmantas Janušonis* - janusonis@psych.ucsb.edu \\ * Corresponding author
}

Published: 25 March 2009

BMC Physiology 2009, 9:4 doi:10.1/186/1472-6793-9-4
Received: 30 August 2008

Accepted: 25 March 2009

This article is available from: http://www.biomedcentral.com/l472-6793/9/4

(c) 2009 Albay et al; licensee BioMed Central Ltd.

This is an Open Access article distributed under the terms of the Creative Commons Attribution License (http://creativecommons.org/licenses/by/2.0), which permits unrestricted use, distribution, and reproduction in any medium, provided the original work is properly cited.

\begin{abstract}
Background: The blood hyperserotonemia of autism is one of the most consistent biological findings in autism research, but its causes remain unclear. A major difficulty in understanding this phenomenon is the lack of information on fundamental interactions among the developing brain, gut, and blood in the mammalian body. We therefore investigated relationships among the body mass, the brain mass, the volume of the hippocampal complex, the gut length, and the whole-blood levels of tryptophan and 5-hydroxytryptamine (5-HT, serotonin) in young, sexually immature wildtype mice.
\end{abstract}

Results: Three-dimensional reconstructions of the hippocampal complex were obtained from serial, Nissl-stained sections and the gut was allowed to attain its maximal relaxed length prior to measurements. The tryptophan and 5-HT concentrations in the blood were assessed with highperformance liquid chromatography (HPLC) and the sex of mice was confirmed by genotyping. Statistical analysis yielded information about correlative relationships among all studied variables. It revealed a strong negative correlation between blood $5-\mathrm{HT}$ concentration and body mass and a strong negative correlation between the brain mass/body mass ratio and gut length. Also, a negative correlation was found between the volume of the hippocampal complex and blood tryptophan concentration.

Conclusion: The study provides information on the covariance structure of several central and peripheral variables related to the body serotonin systems. In particular, the results indicate that body mass should be included as a covariate in studies on platelet 5-HT levels and they also suggest a link between brain growth and gut length.

\section{Background}

The present study was motivated by the platelet hyperserotonemia of autism, a long-standing problem in autism research. It is an extension of our previous experimental and theoretical investigations [1-3] that suggest that the platelet hyperserotonemia is inherently a systems problem in that it requires understanding relationships among various components of the peripheral serotonin (5- 
hydroxytryptamine, 5-HT) system and the developing brain.

The platelet hyperserotonemia of autism is defined as elevated 5-HT levels in the blood platelets of individuals diagnosed with autism spectrum disorders (ASDs) [4-6]. To date, this finding has been replicated by many studies in ethnically diverse autistic groups [7-15]. While a number of genes may contribute to ASD risk [16-21], the replicability of the platelet hyperserotonemia suggests that these genes may affect a small set of biological networks $[3,22]$.

The 5-HT sequestered in platelets is synthesized from tryptophan by enterochromaffin cells in the gut wall [23], with negligible contribution from serotonergic neurons of the enteric nervous system [24]. Some of the gut 5-HT diffuses into the systemic blood circulation, where most of it is rapidly cleared by the liver and lungs $[25,26]$. The remaining free 5-HT in the blood plasma can be taken up by platelets that express the serotonin transporter (SERT). Early studies have suggested that the platelet hyperserotonemia of autism may be caused by altered function of SERT in blood platelets [27]. More recent research has shown that SERT polymorphic variants do partially determine platelet 5-HT uptake rates [28], but that these polymorphisms, alone, do not cause the platelet hyperserotonemia of autism $[28,29]$ or contribute to autism itself [10,30-33]. Other studies have suggested that the platelet hyperserotonemia may be caused by altered 5HT production in the gut [1,34-37], but current experimental evidence remains inconclusive. Also, no link between platelet hyperserotonemia and increased intestinal permeability has been found in children with pervasive developmental disorders [38].

Several studies have recently proposed that the platelet hyperserotonemia of autism may be caused by interactions among several components of the peripheral 5-HT system $[2,14,37,39]$. Specifically, the amount of 5-HT stored in blood platelets may depend on the dynamic interplay among the gastrointestinal system, blood circulation, vascular beds, and platelets themselves [2]. Understanding these interactions in the peripheral 5-HT system may lead to new insights into the normal function of the central nervous system. Tryptophan, the 5-HT precursor, is actively transported across the blood-brain barrier (BBB) and, while 5-HT is generally thought to not cross the BBB, some transfer may occur at elevated 5-HT concentrations [40]. Brain neurons express the same SERT as platelets [41], and SERT is also expressed by brain endothelial cells $[42,43]$. Also, brain and enteric neurons express many of the same serotonin receptors [44].
Our previous theoretical investigation has shown that platelet 5-HT levels may be a function of a number of parameters and their interactions, among them the volume of the circulating blood and the length of the gut [2]. Based on these previous findings, we investigated correlative relationships among several key components of the peripheral 5-HT system and the brain in young, sexually immature mice. Specifically, we measured the body mass, the brain mass, the volume of the hippocampal complex, the relaxed gut length, and the whole-blood 5-HT and tryptophan levels in the same individual wild-type mice at two weeks after birth. In this study, the hippocampal complex served as a convenient brain structure the borders of which are clearly defined in Nissl-stained sections. The hippocampal complex may also play a role in ASDs [4547].

The principal aim of the present study was to reveal the system's covariance structure [48] which can guide experimental design and can be used in advanced, causal modeling. Therefore, strong emphasis was placed on statistical power in an effort to obtain reasonably accurate correlation coefficients, rather than merely significant or non-significant results [49]. One of the advantages of this approach is that the obtained covariance matrix can be combined with results of future studies and used in structural equation modeling, a powerful modeling technique for complex systems.

The focus of the present study was restricted to a postnatal developmental time that may offer insights into central and peripheral alterations in ASDs. We have previously shown that, by two weeks after birth, $5-\mathrm{HT}_{1 \mathrm{~A}}$ receptorknockout mice develop platelet hyperserotonemia [1]. Studies in rats suggest that at this time the development of the hippocampus and the cerebellum are strongly controlled by the state of the brain serotonin system. In the first two postnatal weeks, the expression of $5-\mathrm{HT}_{1 \mathrm{~A}}$ receptors increases in the forebrain, but strongly decreases in the cerebellum [50]. Between postnatal days 10 and 21, the expression of $5-\mathrm{HT}_{1 \mathrm{~A}}$ receptors in the pyramidal cells of the hippocampus shifts from somatic to dendritic and, between postnatal days 10 and 16, the expression of 5$\mathrm{HT}_{1 \mathrm{~A}}$ receptors in S100-positive hippocampal astrocytes declines from $90 \%$ to $20 \%$ [51]. The binding of $5-\mathrm{HT}_{4}$ receptors in the globus pallidus and the substantia nigra sharply increases between postnatal days 9 and 12 and then strongly decreases between postnatal days 12 and 21 [52]. Even though little is known about whether similar changes occur in the human brain, they appear likely since the $5-\mathrm{HT}_{1 \mathrm{~A}}$ expression in the human cerebellum shifts from high in the neonatal stage to very low in adulthood [53] resembling the developmental pattern of 5$\mathrm{HT}_{1 \mathrm{~A}}$ receptor expression in rats [50]. 


\section{Methods \\ Animals}

Timed-pregnant, wild-type CD-1 mice were purchased from Charles River Laboratories, Inc. (Wilmington, MA). They arrived at 15-17 days of gestation and were housed in the UCSB animal facility in individual cages on a 12:12 light-dark cycle (lights on at 07:00, off at 19:00). Mice were checked every morning (before 12:00) and the delivery day was considered to be postnatal day (PD) 0 . The pups were kept with the dam until used. Pups from six litters were analyzed. All litters were normal size (12-14 pups). All experiments were approved by the UCSB Institutional Animal Care and Use Committee.

\section{Tissue harvesting}

A total of 63 pups from 6 litters were used in the study. At postnatal day 14 (5 litters) or 15 ( 1 litter), individual pups were removed from the cage, weighed, and immediately decapitated. The trunk blood was collected into a $1.5 \mathrm{~mL}$ microcentrifuge tube containing $25 \mu \mathrm{L}$ of $5 \% \mathrm{Na}_{2}$ EDTA dissolved in water, as previously described [1]. The tube was immediately pulse-vortexed at low speed and kept at room temperature until the dissections of the brain and gut were completed. Following the dissections, the blood sample was visually examined for blood clots, the volume of the collected blood was measured, and the sample was stored in $20 \mu \mathrm{L}$ aliquots at $-75^{\circ} \mathrm{C}$. The brain was dissected out of the skull with a fine rongeur, immediately weighed in phosphate-buffered saline (0.1 M PBS, $\mathrm{pH}$ 7.2) on a precision balance, immersion-fixed overnight in $4 \%$ paraformaldehyde in PBS at $4{ }^{\circ} \mathrm{C}$, allowed to sink in $30 \%$ sucrose in PBS at $4{ }^{\circ} \mathrm{C}$, and processed as described below. The gastrointestinal tract (the stomach through the rectum) was dissected out of the trunk and allowed to relax in PBS at $4{ }^{\circ} \mathrm{C}$ for $10-13$ days before photographed. The distal tail was stored at $-75^{\circ} \mathrm{C}$ for sex-genotyping. All analyses were done blindly with respect to the values of the other variables in the same individual mice.

\section{Brain}

Following cryoprotection, 17 brains (from 2 litters) were embedded in 20\% gelatin (type A; 275 bloom), immersed in formalin with $20 \%$ sucrose for 3 hours at room temperature, and sectioned coronally on a freezing microtome at $50 \mu \mathrm{m}$ thickness into PBS in 96-well trays. Every lost section was recorded and the percentage of missing sections was not allowed to exceed $9 \%$. The sections were immediately mounted onto glass slides coated with $0.5 \%$ gelatin and $0.05 \%$ chromium potassium sulfate, allowed to airdry, Nissl-stained with $0.25 \%$ thionin, dehydrated in a graded series of ethanols, cleared in Xylenes, and coverslipped with Permount. Since fixation and embedding may alter tissue volume $[54,55]$, care was taken to ensure all brains and sections were exposed to the reagents for the same length of time.
Images of serial sections were captured with a Zeiss Axio Imager $\mathrm{Z} 1$ equipped with a color digital camera (AxioCam HRC Rev. 2) using a $1 \times$ objective (Fig. 1A), imported into the Reconstruct software (version 1.0.9.6; http://syn apses.clm.utexas.edu/tools/index.stm), and the outline of the left hippocampal complex was traced from the most rostral section containing the pyramidal cells to the most caudal section containing the dental gyrus (Figs. 39-64 of [56]). In this rostro-caudal block, the traced regions included the hippocampus proper, the fimbria, the dentate gyrus, the presubiculum, and the subiculum. If a section was missing, the thickness of each of the two neighboring sections was digitally increased by $50 \%$. The quality of tracing was assessed by rotating the 3D-reconstruction and visually inspecting it for discontinuities (Fig. 1B). No digital smoothing was used.

\section{Guts}

To our knowledge, there are no standard protocols for measuring gut length. Since the length of the gut increases considerably after dissection (probably due to muscle relaxation), we investigated this process experimentally (see Results; Fig. 2) and developed a protocol that allowed measuring gut length with high reliability. Following 1013 days of relaxation in $0.1 \mathrm{M}$ PBS (pH 7.2) at $4^{\circ} \mathrm{C}$, gastrointestinal tracts were digitally macro-photographed (Fig. 2A) in $10 \mathrm{~cm}$ Petri dishes with shallow PBS (in order to avoid vertical loops). A millimeter-ruler was included in the images for scale. The images were imported into
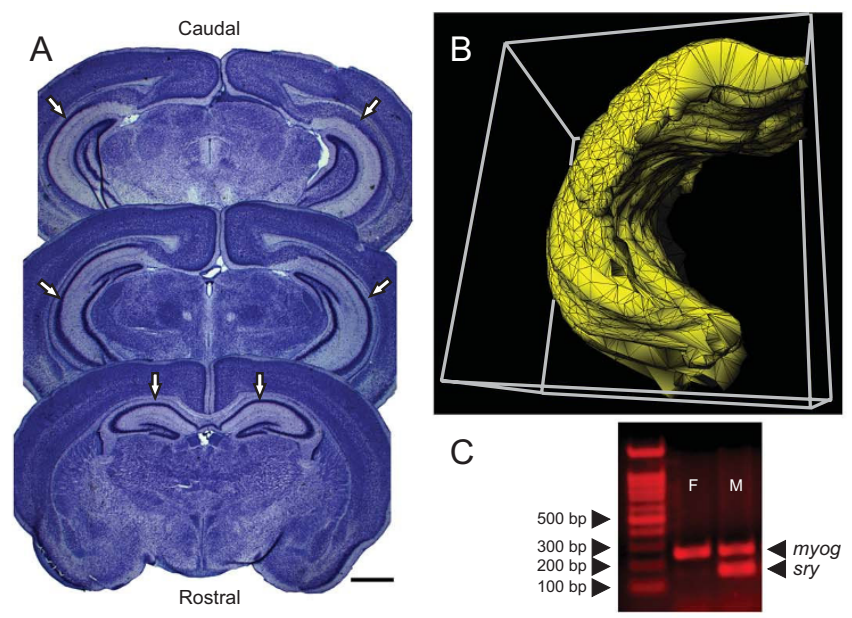

\section{Figure I}

Three-dimensional reconstruction of the hippocampal complex and sex-genotyping. (A) Representative Nissl-stained sections through the mouse brain used in three-dimensional reconstructions of the hippocampal complex. Scale bar is $\mathrm{I} \mathrm{cm}$. (B) A three-dimensional reconstruction of the hippocampal complex. (C) The sry and myog (control) bands in female $(F)$ and male $(M)$ pups detected by sex-genotyping. 

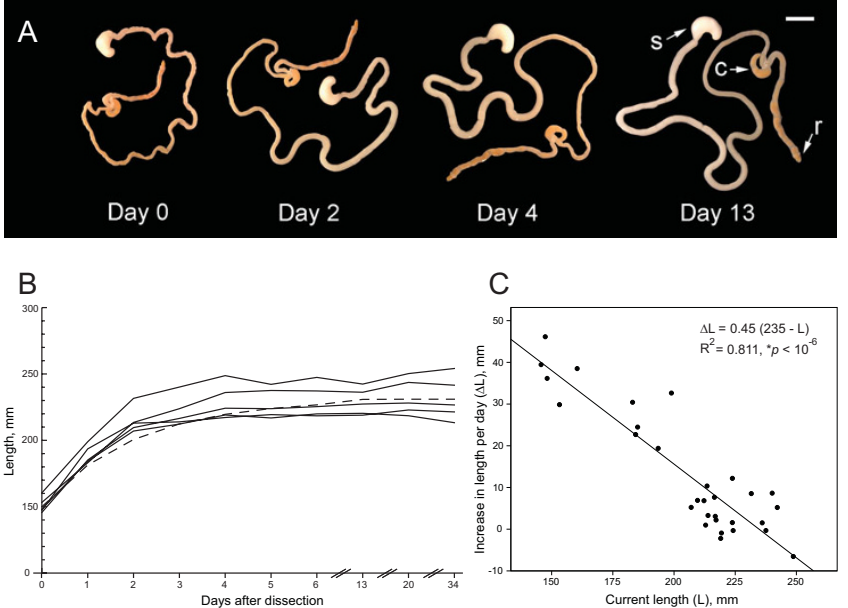

Figure 2

Gut relaxation. (A) The relaxation of the same representative gastrointestinal tract kept in PBS at $4^{\circ} \mathrm{C}$ and photographed at $0,2,4$, and 13 days after dissection.

Abbreviations: s, stomach; c, coecum; r, rectum; scale bar is I $\mathrm{cm}$. (B) The relaxation of five guts (measured from the pylorus of the stomach to the coecum) kept in PBS at $4^{\circ} \mathrm{C}$ and measured over the course 34 days. The dashed line represents the theoretical relaxation (Eq. 2) of a gut with the initial length of $150 \mathrm{~mm}$. (C) The relationship between the current gut length and the increase in gut length per day. The data points were obtained from the five guts used in (b); for better precision of the linear regression (line), only the initial 6 days were included in the analysis. The rate of relaxation was calculated as the absolute difference in length between the current day and the next day.

Reconstruct, and the length of the gut was determined by tracing both sides of the gut from the pylorus of the stomach to the coecum and averaging the length of the two traces. The remaining part of the gut was not measured because it was difficult to control if the dissection included the most distal part of the gastrointestinal tract. This approach produced consistent measures over many days (Fig. 2B) and was superior to obtaining only one trace equidistant from the two sides of the gut.

\section{Whole-blood tryptophan and 5-HT}

The concentration of tryptophan and 5-HT in the blood samples was measured by high-performance liquid chromatography (HPLC) as previously described [1]. Blood samples were prepared by addition of $100 \mu \mathrm{L}$ of $25 \%$ ascorbic acid, $100 \mu \mathrm{L}$ of $5 \%$ sodium metabisulfite, $10 \mu \mathrm{L}$ of $10 \mathrm{ng} / \mu \mathrm{L} \mathrm{N}$-methylserotonin (NMS, internal standard) to frozen whole blood samples. After thawing and mixing, $75 \mu \mathrm{l}$ of $3.4 \mathrm{M}$ perchloric acid was added, the samples were kept on ice for 10 minutes, centrifuged, and the supernate was stored at $-80^{\circ} \mathrm{C}$ until analyzed. Analysis was performed by HPLC with fluorometric detection: a 25 $\times .46$ Altex Ultrasphere column heated to $40^{\circ} \mathrm{C}$ was eluted with a mobile phase consisting of $70 \% 0.1 \mathrm{M} \mathrm{NaH}_{2} \mathrm{PO}_{4}$ (pH 4.7) containing $150 \mathrm{mg} / \mathrm{L}$ octyl sulfate, 20\% methanol. Compounds were detected with a Shimadzu RF 10AXL fluorometer, with excitation and emission wavelengths of 285 and $345 \mathrm{~nm}$, respectively, quantitated by comparing peak heights ratios (analyte/NMS) to those observed for standards, and concentrations expressed as ng per $\mathrm{mL}$. The neurochemicals were determined with typical intra- and inter-assay coefficients of variation of less than $5 \%$ and $10 \%$, respectively. In the final calculations, the dilution of the collected blood in the $\mathrm{Na}_{2} \mathrm{EDTA}$ solution was factored out; therefore, the reported values represent tryptophan and 5-HT concentrations in the undiluted whole blood.

\section{Genotyping}

Since sexing of young mice based on the appearance of their external genitalia is difficult, the anogenital distance can be used as a more reliable measure. In the present study, several organs had to be rapidly extracted destroying the body in the process. Therefore, in order to avoid ambiguity and human errors, mice were sexed by genotyping. This approach also allows permanent storage of the extracted DNA which can be used for future analyses. Genomic DNA was isolated with the DNA Isolation Kit (Lamda, St. Louis, MO). Briefly, $1 \mathrm{~cm}$ of the tail was digested in a lysis buffer at $56^{\circ} \mathrm{C}$ overnight, the DNA was precipitated with ethanol, dissolved in $150 \mu \mathrm{L}$ of TrisEDTA buffer (TE, pH 8.0), and stored at $-20^{\circ} \mathrm{C}$. The sry region located on the $\mathrm{Y}$ chromosome was amplified by polymerase chain reaction (PCR) using the HotStarTaq Master Mix Kit (Qiagen, Valencia, CA). The sry primers were 5'-AACAACTGGGCTTTGCACATTG-3' (forward) and 5'-GTTTATCAGGGTTTCTCTCTAGC-3' (reverse), and the control (myog) primers [57] were 5'-TTACGTCCATCGTGGACAGC-3' (forward), 5'-TGGGCTGGGTGTTAGTCTTA-3' (reverse). The PCR reaction mixture $(50 \mu \mathrm{L})$ contained $25 \mu \mathrm{L}$ of the Master Mix, $1 \mu \mathrm{L}(0.5 \mu \mathrm{M})$ of each primer, $0.5 \mu \mathrm{L}$ of the DNA sample, and $20.5 \mu \mathrm{L}$ water. The amplification was performed in a PxE thermal cycler (ThermoFisher Scientific) with the following conditions: initial activation at $95^{\circ} \mathrm{C}$ for $15 \mathrm{~min}, 33$ cycles of amplification $\left(94^{\circ} \mathrm{C}\right.$ for $40 \mathrm{sec} ; 60^{\circ} \mathrm{C}$ for $40 \mathrm{sec} ; 72^{\circ} \mathrm{C}$ for $\left.1 \mathrm{~min}\right)$, and final extension at $72^{\circ} \mathrm{C}$ for $9 \mathrm{~min}$. The PCR products were run at $120 \mathrm{~V}$ on $1.5 \%$ agarose gel in Tris-acetateEDTA buffer (TAE) containing 5\% ethidium bromide and digitally imaged with a DigiDoc-It UV transillumination system (UVP, Upland, CA). The amplicon sizes were 146 bp/166 bp (sry, doublet) and 245 bp (myog) (Fig. 1C).

\section{Statistical analysis}

Statistical analysis was carried out in SPSS 16.0.2 (SPSS Inc., Chicago, IL). Conceptually, the analysis was based on the general linear model (GLM) that considers correla- 
tion, ANOVA and ANCOVA to be special cases of linear regression [58]. Residuals were tested for normality with the Shapiro-Wilk test (with the level of significance of $p<$ $0.05)$ and for independence with the Durbin-Watson test (DW; independence was assumed if the DW value was in the 1-3 range).

Unless otherwise noted, the forced-entry method was used in linear regression. A non-linear relationship between two variables was considered to be linear "in the parameters" [58], which allowed using standard GLM methods. In backward (stepwise) regression, Fisher's $F$ critical value for variable removal was set at the standard significance level of 0.1. Pearson's correlation between two variables was used if the residuals of the linear regression between these two variables were normally distributed (otherwise, the Mann-Whitney test was used). The emphasis on the normality of residuals rather than of variables themselves follows the standard approach in GLM models. Specifically, it allows treating Student's independent $t$-test as a special case of Pearson's correlation between a continuous variable and a dichotomous variable (e.g., sex; Table 1).

\section{Results \\ Data screening}

The collected data (Additional file 1) for each of the variables were screened for quality blindly with respect to the values of the other variables. As described below, objective criteria were used to eliminate some cases from further analysis. Since in all reconstructed cases the percentage of missing sections in the hippocampal complex did not exceed 9\%, all of the reconstructions were used. Cases with guts clearly damaged during dissection (e.g., split into more than two pieces) were not used in further analyses that included gut length as a variable. We investigated whether the presence of blood clots in some blood samples affected their tryptophan or 5-HT concentration. The mean tryptophan concentrations were not significantly different in the samples with and without blood clots $(t(61)=0.47, p=0.644)$, but the mean 5-HT concentration was significantly lower in the former group $(t(61)=2.44, p=0.018)$. Therefore, cases with blood clots $(N=5)$ were disregarded in all further analyses that included tryptophan or 5-HT as variables.

The collected blood volume varies from case to case and is strongly affected by the constriction of major blood vessels, the angle between the trunk and the collecting tube, and other factors. We therefore asked whether the amount of the collected blood correlated with the measured tryptophan and 5-HT concentrations (if all other parameters are equal and the measurements are accurate, no significant effect should be observed). The correlation between blood sample volume and blood 5-HT concentration was significant $(r=-0.385, p=0.003)$. However, the collected blood volume is also influenced by body size. Therefore, we calculated the partial correlation between blood sample volume and blood 5-HT concentration controlling for body mass and found that this correlation became nonsignificant $(r=-0.085, p=0.532)$. In contrast, the partial correlation between body mass and blood 5-HT concentration controlling for blood sample volume was highly significant $\left(r=-0.495, p=9 \cdot 10^{-5}\right)$. Therefore, all of these cases $(N=58)$ were used in further analyses that included tryptophan or 5-HT as variables. The relationship between body mass and blood 5-HT concentration was investigated further.

ANOVA showed significant litter effects on body mass $\left(F_{5,57}=40.3, p<10^{-6}\right)$, brain mass $\left(F_{5,57}=15.5, p<10^{-6}\right)$, hippocampal volume $\left(F_{1,15}=7.9, p=0.013\right)$, blood tryptophan levels $\left(F_{5,52}=10.8, p<10^{-6}\right)$, blood 5-HT levels $\left(F_{5,52}=16.0, p<10^{-6}\right)$, and a near-significant litter effect on gut length $\left(F_{5,27}=2.54, p=0.052\right)$.

\section{Gut relaxation}

After dissection, the length of the gut increases over the course of several days until it reaches a plateau (Fig. 2A, B). We followed the relaxation of 5 guts in PBS at $4{ }^{\circ} \mathrm{C}$ and plotted the rate of their length increase as a function of their current length (Fig. 2C). Linear regression revealed a strong relationship between these variables $\left(R^{2}=0.811\right.$, $\left.F_{1,28}=120.5, p<10^{-6}\right)$; the residuals were normally distributed $(p=0.18)$ and independent $(\mathrm{DW}=2.45)$. This linear relationship suggests that gut relaxation can be modeled with the differential equation

$$
d L / d t=k\left(L_{0}-L\right)
$$

where $d L / d t$ is the current length increase rate as a function of the current gut length $(L), L_{0}$ is the initial gut length on the dissection day, $\gamma L_{0}$ is the final gut length (where $\gamma>1$ is a constant independent of $L_{0}$ ), and $k$ is the length increase rate constant. Based on Eq. (1), we reanalyzed the gut relaxation data with linear regression using $d L / d t$ as the dependent variable and $L_{0}$ and $L$ as the two predictor variables. Since according to Eq. (1) $d L / d t=0$ when $L_{0}=L$ $=0$, the intercept of the regression line was fixed at the axis origin. The regression revealed that Eq. (1) well describes the relaxation process, since $L_{0}$ and $L$ explained virtually all variance in the length increase rate $\left(R^{2}=0.947, F_{2,28}=\right.$ $\left.250.8, p<10^{-6}\right)$. The residuals were normally distributed $(p=.993)$ and independent $(\mathrm{DW}=1.72)$. The regression yielded $k=0.49$ day $^{-1}$ and $\gamma=1.54$. Since the solution of Eq. (1) is

$$
L(t)=\mathrm{L}_{0}+L_{0} e^{-k t}(1-\gamma)
$$

plugging the obtained numerical $k$ and $\gamma$ values into Eq. (2) shows that, at $4{ }^{\circ} \mathrm{C}$, the gut reaches $95 \%$ of its final 
Table I: Differences between the sex groups and the cross-correlations between the variables

\begin{tabular}{|c|c|c|c|c|c|c|c|c|}
\hline & $\begin{array}{c}M \\
(g)\end{array}$ & $\begin{array}{l}\text { BM } \\
(g)\end{array}$ & $\mathrm{BM} / \mathrm{M}$ & $\underset{\left(\mathrm{mm}^{3}\right)}{\mathbf{H C}}$ & $\begin{array}{c}\text { Trp } \\
(\mathrm{ng} / \mathrm{mL})\end{array}$ & $\begin{array}{c}5-\mathrm{HT} \\
(\mathrm{ng} / \mathrm{mL})\end{array}$ & $\begin{array}{c}\text { 5-HT/ } \\
\text { Trp }\end{array}$ & $\begin{array}{c}\text { Gut } \\
(\mathrm{mm})\end{array}$ \\
\hline \multirow[t]{3}{*}{ Sex } & $F<M$ & $F<M$ & $F>M$ & $F<M$ & $F<M$ & $F>M$ & $\mathrm{~F}>\mathrm{M}^{*}$ & $F>M$ \\
\hline & .185 & .273 & .325 & .286 & .584 & .245 & .040 & .861 \\
\hline & 63 & 63 & 63 & 17 & 58 & 58 & 58 & 33 \\
\hline \multirow[t]{3}{*}{$M$} & & $.768 * *$ & $-.825^{* *}$ & $.662^{* *}$ & -.089 & $-.594 * *$ & $-.304^{*}$ & $.688^{* *}$ \\
\hline & & $<10^{-6}$ & $<10^{-6}$ & .004 & .507 & $10^{-6}$ & .020 & $10^{-5}$ \\
\hline & & 63 & 63 & 17 & 58 & 58 & 58 & 33 \\
\hline \multirow[t]{3}{*}{ BM } & & & -.165 & $.619 * *$ & .056 & $-.433 * *$ & $-.262^{*}$ & $.400 *$ \\
\hline & & & .196 & .008 & .676 & .001 & .047 & .021 \\
\hline & & & 63 & 17 & 58 & 58 & 58 & 33 \\
\hline \multirow[t]{3}{*}{$\mathrm{BM} / \mathrm{M}$} & & & & $-.57 I^{*}$ & .229 & $.465^{* *}$ & $.315^{*}$ & $-.745^{* *}$ \\
\hline & & & & .017 & .084 & $2 \cdot 10^{-4}$ & .016 & $10^{-6}$ \\
\hline & & & & 17 & 58 & 58 & 58 & 33 \\
\hline \multirow[t]{3}{*}{$\mathrm{HC}$} & & & & & $-.638^{* *}$ & $-.505^{*}$ & -.124 & .427 \\
\hline & & & & & .008 & .046 & .649 & .146 \\
\hline & & & & & 16 & 16 & 16 & 13 \\
\hline \multirow[t]{3}{*}{ Trp } & & & & & & .116 & $-.430 * *$ & -.293 \\
\hline & & & & & & .387 & .001 & .110 \\
\hline & & & & & & 58 & 58 & 31 \\
\hline \multirow[t]{3}{*}{ 5-HT } & & & & & & & $.818^{* *}$ & -.264 \\
\hline & & & & & & & $<10^{-6}$ & .152 \\
\hline & & & & & & & 58 & 31 \\
\hline \multirow[t]{3}{*}{ 5-HT/Trp } & & & & & & & & -.004 \\
\hline & & & & & & & & .983 \\
\hline & & & & & & & & 31 \\
\hline $\mathbf{N}$ & 63 & 63 & 63 & 17 & 58 & 58 & 58 & 33 \\
\hline Mean & 6.511 & .387 & .061 & 8.127 & 16424 & 2069 & .128 & 221.30 \\
\hline STD & .954 & .028 & .008 & 1.054 & 2439 & 536 & .037 & 11.25 \\
\hline
\end{tabular}

Abbreviations: M, body mass; BM, brain mass; HC, volume of the hippocampal complex; Trp, blood tryptophan concentration; 5-HT, blood 5-HT concentration; Gut, length of the relaxed gut; N, total number of cases; STD, standard deviation. The two sex groups were compared using the exact Mann-Whitney test if the variable was BM/M or 5-HT/Trp; otherwise, Student's independent $t$-test was used. Spearman's correlation was used if either of the two non-dichotomous variables was BM/M or 5-HT/Trp; otherwise, Pearson's correlation was used. In the sex row, the "greater than" ("less than") sign indicates that the mean of the female group was greater (less) than the mean of the male group. In all other cells, the first number is the value of the correlation coefficient. In all cells, the second (bold) number is the significance of the corresponding test. In all cells, the third number is the total number of cases used in the test. The residuals of the linear regression with sex as the predictor variable and $M$ or 5 $\mathrm{HT}$ as the dependent variable were not normally distributed $\left(p=6 \cdot 10^{-5}\right.$ and $8 \cdot 10^{-6}$, respectively). Therefore, the differences between the mean $M$ and $5-\mathrm{HT}$ values in the two sex groups were retested with the exact Mann-Whitney test, which confirmed they were not significant $(p=0.124$ and 0.168 , respectively).

length $\left(1.54 L_{0}\right)$ in 4 days and $99 \%$ in 7 days. In the present study, we allowed guts to relax for 10-13 days; however, shorter relaxation times (6-8 days) should be sufficient to obtain accurate measurements.

\section{Cross-correlations}

In the initial analysis, the residuals of the linear regression between each of the variable pairs were tested for normality. Of 7 pairs that failed the normality test (irrespective of which of the two variables was the non-dichotomous dependent variable), 5 included at least one of the "ratio variables" ("brain mass/body mass" or "blood 5-HT concentration/blood tryptophan concentration"). This result is expected since the ratio of two normally distributed variables is not normally distributed and can even be bimodal [59]. Based on these results, the Mann-Whitney test was used to compare the "ratio variables" in the two sex groups; for all other variables, Student's $t$-test was used. Likewise, Spearman's correlation coefficient was used to correlate two variables when either of them was a "ratio 
variable"; otherwise, Pearson's correlation was used. The results of these calculations are given in Table 1.

In the interpretation of the results, the Bonferroni correction for multiple tests was used. The type I error $(\alpha=0.05)$ was divided by the total number of tests (36; Table 1 ) to yield the significance level of $\alpha^{*}=0.0013$. As expected, highly significant positive correlations were found between body mass and brain mass $\left(p<10^{-6}\right)$ and between body mass and gut length $\left(p=10^{-5}\right)$. Also, a highly significant negative correlation was found between body mass and the brain/body mass ratio $\left(p<10^{-6}\right)$, possibly due to allometric scaling of brain size.

The cross-correlational analysis revealed a strong negative correlation between body mass and blood 5-HT levels ( $p$ $=10^{-6}$ ). Also, significant correlations were found between brain mass and blood 5-HT levels, and between the brain/ body mass ratio and blood 5-HT levels ( $p=0.001$ and 0.0002 , respectively). Since body mass, brain mass and the brain/body mass ratio cross-correlate, we next tested which of the three variables or their linear combinations could best predict blood 5-HT levels by using stepwise (backward) linear regression. It revealed that body mass, alone, could best predict blood 5-HT levels (Fig. 3A) and that inclusion of the other two variables did not statistically improve this prediction. This model yielded $R^{2}=$ $0.352\left(F_{1,56}=30.5 ; p=10^{-6}\right.$; adjusted $\left.R^{2}=0.341\right)$; the residuals were normally distributed $(p=0.21)$ and independent $(\mathrm{DW}=1.15)$. Since two males had unusually high blood 5-HT concentration (over $3500 \mathrm{ng} / \mathrm{mL}$ ), we next investigated the origin of these outliers and their influence on the regression model. No blood clots were observed in these samples (all cases with blood clots had been eliminated prior to the analysis) and the tryptophan concentration measured in these same samples was in the normal range (Fig. 3B). Since Cook's distances (Cook's D) can be used to estimate the influence of individual cases on a regression model, we calculated this statistic for all regression points and found the largest Cook's $D$ to be 0.66 , below the critical value of 1 . While the two cases could not be eliminated based on any of these objective criteria, we next excluded these two cases and recalculated the regression model. After this adjustment, blood 5-HT concentration was still best predicted by body mass $\left(R^{2}=\right.$ $0.210 ; F_{1,54}=14.3 ; p=0.00039 ;$ adjusted $\left.R^{2}=0.195\right)$.

All pups with body mass less than $5 \mathrm{~g}$ came from the same litter. Their tissues were collected at PD14, the same developmental time at which the other four litters were processed. The litter was normal size (14 pups; another litter had the same number of pups) and the pups showed no gross anatomical abnormalities. These pups were used in all the other analyses (including the reconstruction of the hippocampal complex) and did not appear to be outliers there (Fig. 3C, D). The correlation between body mass and blood 5-HT remained significant if only the litter means were considered (Fig. 4A).

Next, we analyzed the strong correlation between gut length and the brain/body mass ratio $\left(p=10^{-6}\right)$. Since the residuals of the linear regression between these two variables were not distributed normally ( $p=0.03$ ), we modeled their relationship with a quadratic polynomial (Fig. 3C). The regression yielded $R^{2}=0.621\left(F_{2,30}=24.6, p<10^{-6}\right.$; adjusted $R^{2}=0.596$ ); the residuals were normally distributed $(p=0.26)$ and independent $(\mathrm{DW}=1.16)$. The constant at the quadratic term was significantly different from zero $(t(30)=3.36, p=0.002)$, further supporting the nonlinearity of the relationship. The correlation between gut length and the brain/body mass ratio remained significant if only the litter means were considered (Fig. 4B).

The correlation between blood tryptophan concentration and hippocampal complex volume did not meet the significance criterion after the Bonferroni correction. However, it was highly significant considered separately (Fig. $3 D)$. The linear regression yielded $R^{2}=0.407\left(F_{1,14}=9.63\right.$, $p=0.008$; adjusted $\left.R^{2}=0.365\right)$; the residuals were normally distributed $(p=0.58)$ and independent $(\mathrm{DW}=$ 1.40).

\section{Discussion}

To date, relationships among body mass, brain mass, gut length, and whole-blood tryptophan and 5-HT levels have not been systematically investigated in a genetically uniform population of any mammalian species. Table 1 provides information for future top-down $[2,25]$ and bottom-up (e.g., structural equation modeling) studies and can also be used in the design of multidimensional experiments where a priori considerations of statistical power are important.

We found a strong negative correlation between body mass and whole-blood 5-HT levels. The strength of this relationship was influenced by the presence of several pups with low body mass but no gross anatomical abnormalities. The elevated blood 5-HT levels were unlikely to be caused by developmental delay, since blood 5-HT levels increase, not decrease, during postnatal development in mice [1]. It has been reported that extremely low levels of maternal peripheral 5-HT result in smaller mouse embryos that also exhibit abnormalities in many organ systems $[60,61]$. It is intriguing to speculate that a less severe decrease in maternal peripheral 5-HT may also result in reduced body mass and compensatory overproduction of peripheral 5-HT in the offspring. However, peripheral administration of the immediate 5 -HT precursor 5-hydroxytryptophan (5-HTP) to pregnant rats also leads to embryos with reduced body mass [62]. 

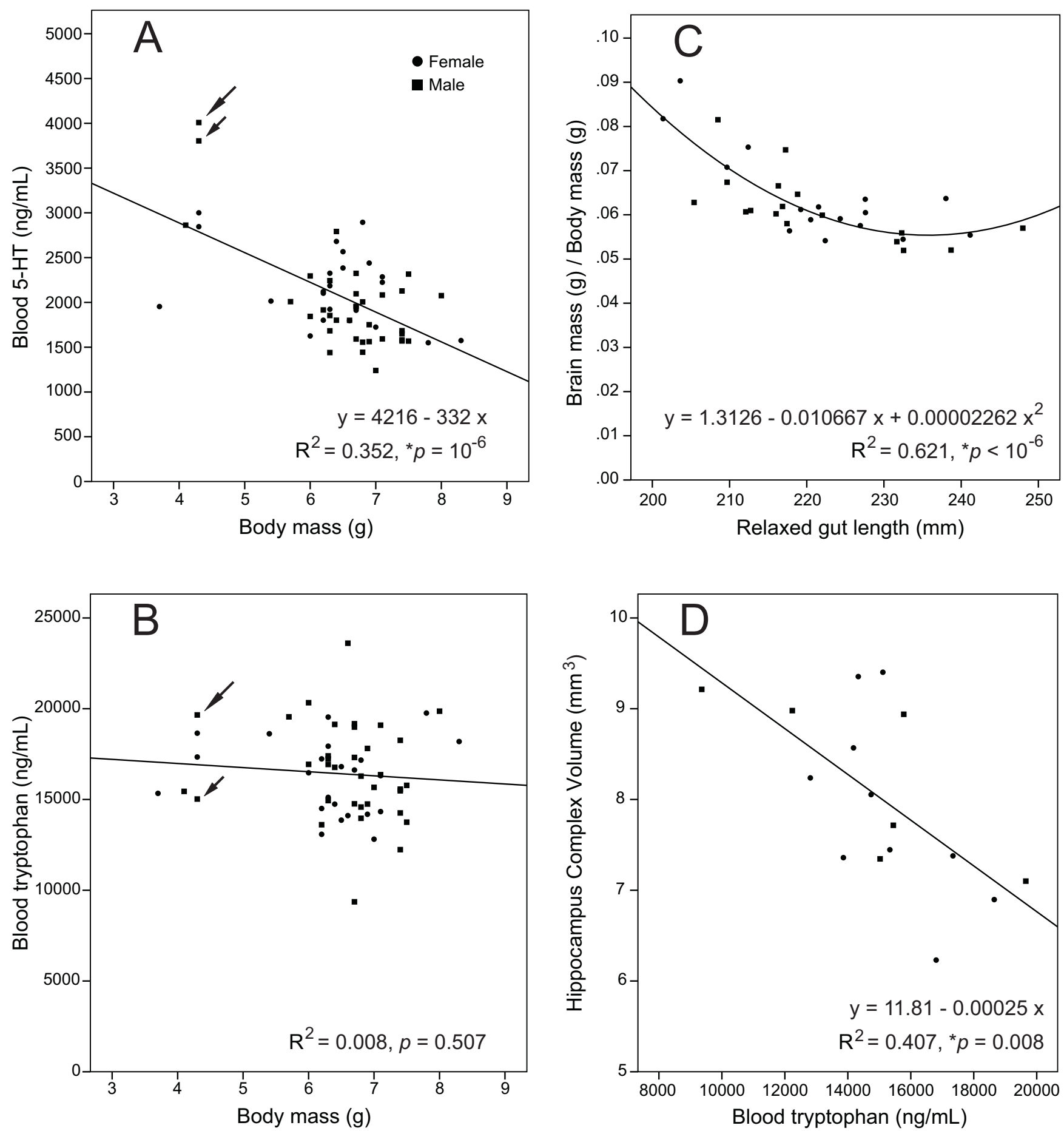

Figure 3

Relationships between highly correlated variables. (A) The relationship between body mass and blood 5-HT concentration. The long and short arrows indicate two potential outliers with high blood 5-HT concentration. (B) The blood tryptophan concentration of the two potential outliers in (A) appears to be normal (the corresponding arrows). (C) The relationship between gut length and the brain/body mass ratio. (D) The relationship between blood tryptophan concentration and the volume of the hippocampal complex. 



Figure 4

Relationships between the litter means of highly correlated variables. (A) The relationship between the litter means of body mass and blood 5-HT concentration. (B) The relationship between the litter means of gut length and the brain/body mass ratio. In $(\mathbf{A})$ and $(\mathbf{B})$, point \#N (M) represents litter $N$ with $M$ cases analyzed; the horizontal and vertical bars represent the standard errors of the means.

The observed relationship between body mass and blood 5 -HT levels is predicted by our theoretical model of platelet 5-HT levels [2]. According to the model (equations $(22)$ and (27) of [2]), platelet 5-HT levels $(P)$ are given by the following equation:

$$
P=\left[a Q\left(b+\Omega_{g}^{-1}\right)+c\right]^{-1}
$$

where $Q$ is the total cardiac output, $\Omega_{g}$ is the volume of the gut wall, and where the positive $a, b$, and $c$ can be considered constant in this study. The cardiac output is likely to be directly proportional to body mass (i.e., $Q=k M$, where $M$ is body mass and $k$ is a positive constant). Gut length also scales with body mass (Table 1), but an increase in body mass is unlikely to increase gut length by the same factor. Therefore, the volume of the gut wall may scale as $\Omega_{g}=r M^{(1 / h)}+s$, where $r>0, s \geq 0$, and $h \geq 1$ are constants. This allows expressing $P$ as a function of $M$ and, since the derivative of $P$ with respect to $M$ is always negative (i.e., $d P / d M<0)$, platelet 5 -HT concentration should decrease as body mass increases. Importantly, this relationship may not hold true for developmental processes [1] because other parameters, here considered constant (e.g., the levels of extracellular 5-HT in the gut wall, the platelet 5-HT uptake rate constant; see Janušonis (2008)), may undergo developmental changes.

Body mass is almost never controlled for in experimental studies on the platelet hyperserotonemia of autism
$[9,11,12]$. In light of the present findings, including body mass as a covariate may reduce uncontrolled variability in platelet 5-HT levels. Recent findings show that low birth mass may carry an increased risk for ASDs [63] and that head circumference strongly correlates with body mass in ASD patients [64]. Intriguingly, the maturation of thalamocortical projections appears to be influenced by body mass in normal mice [65].

We found a non-linear relationship between gut length and the brain/body mass ratio. While there appears to be little association between the brain/body mass ratio and the relaxed gut length if guts are average length, short guts predict a higher brain/body mass ratio (Fig. 3C). The biological nature of this relationship is unclear. It is conceivable that the length of the gut modulates how much tryptophan reaches the systemic blood circulation and, since tryptophan can cross the $\mathrm{BBB}$, its availability in the brain may affect brain growth through 5 -HT synthesis [66]. Intriguingly, it has been recently hypothesized that a decrease in gut length has had a major impact on the evolution of the human brain $[67,68]$.

The analysis also suggested a tentative relationship between blood tryptophan levels and the volume of the developing hippocampal complex. Tryptophan depletion is known to affect the development and function of the hippocampus [69-71]. Our results suggest that even relatively small, natural fluctuations of blood tryptophan lev- 
els may modulate its size. Interestingly, at PD14, the mean blood tryptophan concentration in the CD-1 strain $(16424 \mathrm{ng} / \mathrm{mL})$ was considerably higher than that in the C57BL/6 strain $(11563 \mathrm{ng} / \mathrm{mL})$ [1]. Since the tryptophan levels were assessed by the same method in both studies, a statistical comparison between them suggests that this difference between the two strains is significant $(t(66)=$ $\left.6.17, p=4.7 \cdot 10^{-8}\right)$. It would be interesting to know if the mean volumes of the hippocampal complex also differ in these strains.

No sex differences were observed with regard to all variables. The marginally significant sex difference between the blood 5-HT/tryptophan ratios could be spurious considering the large number of tests. Also, the correlation between blood tryptophan and 5-HT was non-significant, consistent with previous reports in humans [34] and in C57BL/6 mice at postnatal day 14 [1].

The strong statistical relationships found in the present study should be cross-validated in other mouse strains and (when feasible) in humans. It should be noted that all of the reported relationships are empirical and do not imply direct causality; however, these findings may stimulate further experimental research where causality in addressed. For instance, mice lacking the serotonin 5$\mathrm{HT}_{1 \mathrm{~A}}$ receptor show elevated levels of anxiety [72] and develop an autistic-like blood hyperserotonemia [1]. While these two phenomena may appear unrelated, they may be explained by the expression of $5-\mathrm{HT}_{1 \mathrm{~A}}$ receptors both in the brain $[51,73,74]$ and in the gut [75]. Serotonin $5-\mathrm{HT}_{4}$ receptors play important roles in the developing brain [76,77] and the gut [44,78], and recently $5-\mathrm{HT}_{4}$ mRNA has been reported in blood platelets [79]. Therefore, altered expression of $5-\mathrm{HT}_{4}$ receptors may simultaneously affect all of these subsystems, even if they are separated by the BBB. Experimental methods, used in combination with modern statistical approaches, can provide important information about the interactions among components of the peripheral and central 5-HT systems, which are often studied in isolation.

\section{Conclusion}

The study provides information on the covariance structure of several variables related to the central and peripheral serotonin systems. In particular, the results indicate that body mass should be included as a covariate in studies on platelet 5-HT levels and they also suggest a link between brain growth and gut length.

\section{Authors' contributions}

RA, AC, and MT performed the brain and gut analyses; AC genotyped the pups; GMA performed the blood HPLC analysis; SJ, RA, and GMA analyzed the results; SJ con- ceived the project, supervised all of its stages, and wrote the manuscript.

\section{Additional material}

\section{Additional file 1}

The data set used in the study.

Click here for file

[http://www.biomedcentral.com/content/supplementary/14726793-9-4-S1.xls]

\section{Acknowledgements}

We thank Rebecca M. Maichrowicz for her assistance with brain histology and llya Shifrovich for his assistance with HPLC. This research was supported by the UCSB-Santa Barbara Cottage Hospital Special Research Award (SJ) and UCSB URCA grants (RA and MT).

\section{References}

I. Janušonis S, Anderson GM, Shifrovich I, Rakic P: Ontogeny of brain and blood serotonin levels in 5-HT mice: potential relevance to the neurobiology of autism. J Neurochem 2006, 99:1019-1031.

2. Janušonis S: Origin of the blood hyperserotonemia of autism. Theor Biol Med Model 2008, 5: 10 .

3. Janušonis S: Autism as a theoretical problem and the significance of blood hyperserotonemia. In Causes and Risks for Autism Edited by: Giordano AC, Lombardi VA. Hauppauge, NY: Nova Science Publishers; 2009.

4. Anderson GM, Horne WC, Chatterjee D, Cohen DJ: The hyperserotonemia of autism. Ann N Y Acad Sci 1990, 600:331-340.

5. Anderson GM: Genetics of childhood disorders: XLV. Autism, part 4: serotonin in autism. J Am Acad Child Adolesc Psychiatry 2002, 41:1513-1516.

6. Cook EH, Leventhal BL: The serotonin system in autism. Curr Opin Pediatr 1996, 8:348-354.

7. Hanley HG, Stahl SM, Freedman DX: Hyperserotonemia and amine metabolites in autistic and retarded children. Arch Gen Psychiatry 1977, 34:52I-53I.

8. Anderson GM, Freedman DX, Cohen DJ, Volkmar FR, Hoder EL, McPhedran P, Minderaa RB, Hansen CR, Young JG: Whole blood serotonin in autistic and normal subjects. J Child Psychol Psychiatry 1987, 28:885-900.

9. McBride PA, Anderson GM, Hertzig ME, Snow ME, Thompson SM, Khait VD, Shapiro T, Cohen DJ: Effects of diagnosis, race, and puberty on platelet serotonin levels in autism and mental retardation. J Am Acad Child Adolesc Psychiatry 1998, 37:767-776.

10. Coutinho AM, Oliveira G, Morgadinho T, Fesel C, Macedo TR, Bento C, Marques C, Ataide A, Miguel T, Borges L, et al.: Variants of the serotonin transporter gene (SLC6A4) significantly contribute to hyperserotonemia in autism. Mol Psychiatry 2004, 9:264-27I.

II. Mulder EJ, Anderson GM, Kema IP, De BA, Van Lang ND, Den Boer JA, Minderaa RB: Platelet serotonin levels in pervasive developmental disorders and mental retardation: Diagnostic group differences, within-group distribution, and behavioral correlates. J Am Acad Child Adolesc Psychiatry 2004, 43:49I-499.

12. Hranilovic D, Bujas-Petkovic Z, Vragovic R, Vuk T, Hock K, Jernej B: Hyperserotonemia in adults with autistic disorder. J Autism Dev Disord 2007, 37: 1934-1940.

13. Melke J, Goubran BH, Chaste P, Betancur C, Nygren G, Anckarsater $\mathrm{H}$, Rastam M, Stahlberg O, Gillberg IC, Delorme R, et al.: Abnormal melatonin synthesis in autism spectrum disorders. Mol Psychiatry 2008, 13:90-98.

14. Hranilovic D, Novak R, Babic M, Novokmet M, Bujas-Petkovic Z, Jernej $B$ : Hyperserotonemia in autism: the potential role of 5HT-related gene variants. Coll Antropol 2008, 32(Suppl I): $75-80$. 
15. Schain RJ, Freedman DX: Studies on 5-hydroxyindole metabolism in autistic and other mentally retarded children. J Pediatr I96I, 58:315-320.

16. Zhao X, Leotta A, Kustanovich V, Lajonchere C, Geschwind DH, Law K, Law P, Qiu S, Lord C, Sebat J, et al:: A unified genetic theory for sporadic and inherited autism. Proc Natl Acad Sci USA 2007, I04:|283|-|2836.

17. Szatmari P, Paterson AD, Zwaigenbaum L, Roberts W, Brian J, Liu XQ, Vincent JB, Skaug JL, Thompson AP, Senman L, et al.: Mapping autism risk loci using genetic linkage and chromosomal rearrangements. Nat Genet 2007, 39:319-328.

18. Abrahams BS, Geschwind $\mathrm{DH}$ : Advances in autism genetics: on the threshold of a new neurobiology. Nat Rev Genet 2008, 9:341-355

19. Christian SL, Brune CW, Sudi J, Kumar RA, Liu S, Karamohamed S Badner JA, Matsui S, Conroy J, McQuaid D, et al.: Novel submicroscopic chromosomal abnormalities detected in autism spectrum disorder. Biol Psychiatry 2008, 63: I I I I- I I I7.

20. Sebat J, Lakshmi B, Malhotra D, Troge J, Lese-Martin C, Walsh T, Yamrom B, Yoon S, Krasnitz A, Kendall J, et al.: Strong association of de novo copy number mutations with autism. Science 2007 , 3 1 6:445-449.

21. Lintas C, Persico AM: Autistic phenotypes and genetic testing: state-of-the-art for the clinical geneticist. J Med Genet 2009, 46: $1-8$.

22. Geschwind DH: Autism: many genes, common pathways? Cell 2008, I 35:391-395.

23. Gershon MD: Review article: serotonin receptors and transporters - roles in normal and abnormal gastrointestinal motility. Aliment Pharmacol Ther 2004, 20(Suppl 7):3-14.

24. Walther DJ, Peter JU, Bashammakh S, Hortnagl H, Voits M, Fink H, Bader M: Synthesis of serotonin by a second tryptophan hydroxylase isoform. Science 2003, 299:76.

25. Anderson GM, Stevenson JM, Cohen DJ: Steady-state model for plasma free and platelet serotonin in man. Life Sci 1987, 4I:1777-1785

26. Thomas DP, Vane JR: 5-hydroxytryptamine in the circulation of the dog. Nature 1967, 216:335-338.

27. Cook EH Jr, Courchesne R, Lord C, Cox NJ, Yan S, Lincoln A, Haas $R$, Courchesne E, Leventhal BL: Evidence of linkage between the serotonin transporter and autistic disorder. Mol Psychiatry 1997, 2:247-250.

28. Anderson GM, Gutknecht L, Cohen DJ, Brailly-Tabard S, Cohen JH, Ferrari P, Roubertoux PL, Tordjman S: Serotonin transporter promoter variants in autism: functional effects and relationship to platelet hyperserotonemia. Mol Psychiatry 2002, 7:831-836

29. Persico AM, Pascucci T, Puglisi-Allegra S, Militerni R, Bravaccio C Schneider C, Melmed R, Trillo S, Montecchi F, Palermo M, et al.: Serotonin transporter gene promoter variants do not explain the hyperserotoninemia in autistic children. Mol Psychiatry 2002, 7:795-800.

30. Persico AM, Militerni R, Bravaccio C, Schneider C, Melmed R, Conciatori M, Damiani V, Baldi A, Keller F: Lack of association between serotonin transporter gene promoter variants and autistic disorder in two ethnically distinct samples. Am J Med Genet 2000, 96:123-127.

31. Wu S, Guo Y, Jia M, Ruan Y, Shuang M, Liu J, Gong X, Zhang Y, Yang J, Yang $X$, et al.: Lack of evidence for association between the serotonin transporter gene (SLC6A4) polymorphisms and autism in the Chinese trios. Neurosci Lett 2005, 38I: I-5.

32. Ramoz N, Reichert JG, Corwin TE, Smith CJ, Silverman JM, Hollander $E$, Buxbaum JD: Lack of evidence for association of the serotonin transporter gene SLC6A4 with autism. Biol Psychiatry 2006, 60:186-19|.

33. Wendland JR, DeGuzman TB, McMahon F, Rudnick G, tera-Wadleigh SD, Murphy DL: SERT Ileu425Val in autism, Asperger syndrome and obsessive-compulsive disorder. Psychiatr Genet 2008, I 8:31-39.

34. Minderaa RB, Anderson GM, Volkmar FR, Akkerhuis GW, Cohen DJ: Urinary 5-hydroxyindoleacetic acid and whole blood serotonin and tryptophan in autistic and normal subjects. Biol Psychiatry 1987, 22:933-940.

35. Croonenberghs J, Verkerk R, Scharpe S, Deboutte D, Maes M: Serotonergic disturbances in autistic disorder: L-5-hydroxytryptophan administration to autistic youngsters increases the blood concentrations of serotonin in patients but not in controls. Life Sci 2005, 76:2171-2183.

36. Janušonis S: Statistical distribution of blood serotonin as a predictor of early autistic brain abnormalities. Theor Biol Med Model 2005, 2:27.

37. Coutinho AM, Sousa I, Martins M, Correia C, Morgadinho T, Bento C, Marques C, Ataide A, Miguel TS, Moore JH, et al.: Evidence for epistasis between SLC6A4 and ITGB3 in autism etiology and in the determination of platelet serotonin levels. Hum Genet 2007, I 2 I:243-256.

38. Kemperman RF, Muskiet FD, Boutier AI, Kema IP, Muskiet FA: Brief report: normal intestinal permeability at elevated platelet serotonin levels in a subgroup of children with pervasive developmental disorders in Curacao (The Netherlands antiIles). J Autism Dev Disord 2008, 38:40 I-406.

39. Carneiro AM, Cook EH, Murphy DL, Blakely RD: Interactions between integrin alphallbbeta 3 and the serotonin transporter regulate serotonin transport and platelet aggregation in mice and humans. J Clin Invest 2008, I I 8: I 544- I 552

40. Nakatani Y, Sato-Suzuki I, Tsujino N, Nakasato A, Seki Y, Fumoto M, Arita $\mathrm{H}$ : Augmented brain 5-HT crosses the blood-brain barrier through the 5-HT transporter in rat. Eur J Neurosci 2008 , 27:2466-2472.

4I. Lesch KP, Wolozin BL, Murphy DL, Reiderer P: Primary structure of the human platelet serotonin uptake site: identity with the brain serotonin transporter. I Neurochem 1993, 60:2319-2322.

42. Brust P, Friedrich A, Krizbai IA, Bergmann R, Roux F, Ganapathy V, Johannsen B: Functional expression of the serotonin transporter in immortalized rat brain microvessel endothelial cells. J Neurochem 2000, 74: I 24I-I 248.

43. Wakayama K, Ohtsuki S, Takanaga H, Hosoya K, Terasaki T: Localization of norepinephrine and serotonin transporter in mouse brain capillary endothelial cells. Neurosci Res 2002 44:173-180.

44. Gershon MD, Tack J: The serotonin signaling system: From basic understanding to drug development for functional GI disorders. Gastroenterology 2007, | 32:397-4|4.

45. Aylward EH, Minshew NJ, Goldstein G, Honeycutt NA, Augustine AM, Yates KO, Barta PE, Pearlson GD: MRI volumes of amygdala and hippocampus in non-mentally retarded autistic adolescents and adults. Neurology 1999, 53:2145-2I50.

46. Nicolson R, DeVito TJ, Vidal CN, Sui Y, Hayashi KM, Drost DJ, Williamson PC, Rajakumar N, Toga AW, Thompson PM: Detection and mapping of hippocampal abnormalities in autism. Psychiatry Res 2006, | 48: ||-2|.

47. Sparks BF, Friedman SD, Shaw DW, Aylward EH, Echelard D, Artru AA, Maravilla KR, Giedd JN, Munson J, Dawson G, et al.: Brain structural abnormalities in young children with autism spectrum disorder. Neurology 2002, 59: 184-192.

48. Kline RB: Principles and practice of structural equation modeling Second edition. New York: The Guilford Press; 2005.

49. Cohen J: The earth is round $(p<.05)$. Am Psychologist 1994, 49:997-1003.

50. Miquel MC, Kia HK, Boni C, Doucet E, Daval G, Matthiessen L, Hamon M, Verge D: Postnatal development and localization of 5-HT, receptor $m$ RNA in rat forebrain and cerebellum. Brain Res Dev Brain Res 1994, 80:|49-I57.

51. Patel TD, Zhou FC: Ontogeny of 5-HT ${ }_{\text {IA }}$ receptor expression in the developing hippocampus. Brain Res Dev Brain Res 2005, I 57:42-57.

52. Waeber C, Sebben M, Nieoullon A, Bockaert J, Dumuis A: Regiona distribution and ontogeny of $5-\mathrm{HT}_{4}$ binding sites in rodent brain. Neuropharmacology 1994, 33:527-54I.

53. del Olmo E, Diaz A, Guirao-Pineyro M, del Arco C, Pascual J, Pazos A: Transient localization of $5-\mathrm{HT}_{\text {IA }}$ receptors in human cerebellum during development. Neurosci Lett 1994, I66:149-152.

54. Blinkov SM, Glezer II: The Human Brain in Figures and Tables: A Quantitative Handbook New York, NY: Plenum Press; 1968.

55. Baker JR: Principles of Biological Microtechnique London: Methuen \& Co, Ltd; 1958.

56. Paxinos G, Franklin KBJ: The Mouse Brain in Steterotaxic Coordinates: Deluxe Edition of the Atlas Second edition. San Diego, CA: Academic Press; 200I.

57. McClive PJ, Sinclair AH: Rapid DNA extraction and PCR-sexing of mouse embryos. Mol Reprod Dev 200I, 60:225-226. 
58. Cohen J, Cohen P, West SG, Aiken LS: Applied Multiple Regression/Correlation Analysis for the Behavioral Sciences Third edition. Mahwah, NJ: Lawrence Erlbaum Associates; 2003.

59. Pham-Gia T, Turkkan N, Marchand E: Density of the ratio of two normal random variables and applications. Comm Stat Theory Meth 2006, 35:1569-I59I.

60. Cote F, Fligny C, Bayard E, Launay JM, Gershon MD, Mallet J, Vodjdan $\mathrm{G}$ : Maternal serotonin is crucial for murine embryonic development. Proc Natl Acad Sci USA 2007, I 04:329-334.

61. Fligny C, Fromes Y, Bonnin P, Darmon M, Bayard E, Launay JM, Cote $F$, Mallet J, Vodjdani G: Maternal serotonin influences cardiac function in adult offspring. FASEB / 2008, 22:2340-2349.

62. Salas SP, Giacaman A, Romero W, Downey P, Aranda E, Mezzano D, Vio CP: Pregnant rats treated with a serotonin precursor have reduced fetal weight and lower plasma volume and kallikrein levels. Hypertension 2007, 50:773-779.

63. Schendel D, Bhasin TK: Birth weight and gestational age characteristics of children with autism, including a comparison with other developmental disabilities. Pediatrics 2008, | 2 |: | | 55- | | 64.

64. Sacco R, Militerni R, Frolli A, Bravaccio C, Gritti A, Elia M, Curatolo P, Manzi B, Trillo S, Lenti C, et al.: Clinical, morphological, and biochemical correlates of head circumference in autism. Biol Psychiatry 2007, 62:1038-1047.

65. Hoerder-Suabedissen A, Paulsen O, Molnar Z: Thalamocortical maturation in mice is influenced by body weight. J Comp Neurol 2008, 5 I I:4I 5-420.

66. Whitaker-Azmitia PM: Serotonin and brain development: role in human developmental diseases. Brain Res Bull 2001, 56:479-485

67. Wobber V, Hare B, Wrangham R: Great apes prefer cooked food. J Hum Evol 2008, 55:340-348.

68. Gibbons A: Paleoanthropology. Food for thought. Science 2007 3 16:1558-1560.

69. Olivier JD, Jans LA, Korte-Bouws GA, Korte SM, Deen PM, Cools AR, Ellenbroek BA, Blokland A: Acute tryptophan depletion dose dependently impairs object memory in serotonin transporter knockout rats. Psychopharmacology (Berl) 2008, 200:243-254.

70. Uchida S, Umeeda H, Kitamoto A, Masushige S, Kida S: Chronic reduction in dietary tryptophan leads to a selective impairment of contextual fear memory in mice. Brain Res 2007, I | 49: |49-156.

7I. Feria-Velasco A, del Angel AR, Gonzalez-Burgos I: Modification of dendritic development. Prog Brain Res 2002, I 36: I 35- I 43.

72. Gross C, Zhuang X, Stark K, Ramboz S, Oosting R, Kirby L, Santarelli

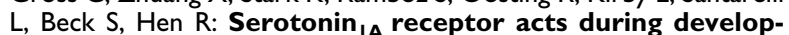
ment to establish normal anxiety-like behaviour in the adult. Nature 2002, 4 I 6:396-400.

73. Adell A, Celada P, Abellan MT, Artigas F: Origin and functional role of the extracellular serotonin in the midbrain raphe nuclei. Brain Res Brain Res Rev 2002, 39: I54-180.

74. Bar-Peled O, Gross-Isseroff R, Ben Hur H, Hoskins I, Groner Y, Biegon A: Fetal human brain exhibits a prenatal peak in the density of serotonin 5-HT IA receptors. Neurosci Lett 1991, 127:173-176.

75. Kirchgessner AL, Liu MT, Raymond JR, Gershon MD: Identification of cells that express 5-hydroxytryptaminelA receptors in the nervous systems of the bowel and pancreas. J Comp Neurol 1996, 364:439-455.

76. Manzke T, Preusse S, Hulsmann S, Richter DW: Developmental changes of serotonin 4(a) receptor expression in the rat preBotzinger complex. J Comp Neurol 2008, 506:775-790.

77. Waeber C, Sebben M, Bockaert J, Dumuis A: Regional distribution and ontogeny of $\mathbf{5}-\mathrm{HT}_{4}$ binding sites in rat brain. Behav Brain Res 1996, 73:259-262.

78. Liu M, Geddis MS, Wen Y, Setlik W, Gershon MD: Expression and function of 5-HT4 receptors in the mouse enteric nervous system. Am J Physiol Gastrointest Liver Physiol 2005, 289:GII48-GII63.

79. Amisten S, Braun OO, Bengtsson A, Erlinge D: Gene expression profiling for the identification of $\mathbf{G}$-protein coupled receptors in human platelets. Thromb Res 2008, I 22:47-57.
Publish with Biomed Central and every scientist can read your work free of charge

"BioMed Central will be the most significant development for disseminating the results of biomedical research in our lifetime. "

Sir Paul Nurse, Cancer Research UK

Your research papers will be:

- available free of charge to the entire biomedical community

- peer reviewed and published immediately upon acceptance

- cited in PubMed and archived on PubMed Central

- yours - you keep the copyright
BiolMedcentral 